\title{
Spatial Patterns of Pulmonary Tuberculosis: Analysing Rainfall Patterns in Visual Formation
}

\author{
Hendra Rohman \\ Health Polytechnic of Bhakti Setya Indonesia, Yogyakarta, Indonesia
}

\begin{abstract}
Article Info
Article history:

Received Dec 10, 2017

Revised Feb 20, 2018

Accepted Mar 6, 2018

\section{Keyword:}

Geographical information systems

Mycobacterium tuberculosis

Pulmonary tuberculosis

ABSTRACT

Management sustainability related tuberculosis patient treatment was limited. Tuberculosis analysis was still in the form of data aggregation. This is cross sectional survey using geographical information system, analyzed by descriptive methods, the sample included 162 pulmonary tuberrculosis patient in 2014. The variables were pulmonary tuberrculosis patients and isohyet data. Mycrobacterium tuberculosis will be survive and multiply during rainy season. Rainfall data was an increasing pattern from first quarter to fourth quarter in 2014, however data in 2011, 2012 and 2013, which each quarter was largely experiencing sustained increase and decline. Pulmonary tuberrculosis patients were most prevalent in 2014. It was increase in the rainy season. The most high rainfall intensity $(>2400 \mathrm{~mm}$ ) in east of Lendah and western of Kokap areas, while the lowest intensity $(<1500 \mathrm{~mm})$ in east of Nanggulan, in the south of Panjatan and Galur areas. It was mostly located in areas with high rainfall intensity $(2200-2400 \mathrm{~mm})$ which spreads and stretches in Sentolo, Wates, and Panjatan areas. Pulmonary tuberrculosis occurred over the rainy season. Spatial pattern distribution of pulmonary tuberrculosis patients in high rainfall intensity spreads and stretches from east to west areas. Active case monitoring program should be performed by tuberculosis program that concerned in areas of high rainfall intensity.
\end{abstract}

Copyright $@ 2018$ Institute of Advanced Engineering and Science. All rights reserved.

\section{Corresponding Author:}

Hendra Rohman,

Medical Record and Health Information,

Health Polytechnic of Bhakti Setya Indonesia, Yogyakarta, Indonesia,

Jl. Janti Gedongkuning No.336 Yogyakarta, Indonesia.

Email: hendrarohman@mail.ugm.ac.id

\section{INTRODUCTION}

The Indonesian region is called the maritime continent, because this region consists of many islands surrounded by warmer sea water. Convection in general (except for dry season) is more active than in the other tropical regions, which act as the heat engine to drive the east-west circulation. This active convection provides a large amount of rainfall, and geographic and interannual variations of the convection activity, and rainfall, are major evidences of climate variations in the tropics [1]. The role of Indonesian seas was investigated to determine the effects of the ocean on rainfall characteristics. Indonesian Seas was potential on Rainfall Intensity. The analysis showed that the related difference between the Pacific and Indian Oceans could affect the rainfall characteristics [2]. Research so far has mostly focused on thermal stress, extreme weather events, and infectious diseases, with some attention to estimates of future regional food yields and hunger prevalence. An emerging broader approach addresses a wider spectrum of health risks due to the social, demographic, and economic disruptions of climate change. Evidence and anticipation of adverse health effects will strengthen the case for pre-emptive policies, and will also guide priorities for planned adaptive strategies [3]. Climate change refers to long term shifts in weather conditions and patterns of extreme weather events. It may lead to changes in health threat to human beings, multiplying existing health problems. Humans' vulnerability to the potential health impacts by climate change is evident in literature. As 
an active agent, human beings may control the related health effects that may be effectively controlled through adopting proactive measures, including better understanding of the climate change patterns and of the compound disease specific health effects, and effective allocation of technologies and resources to promote healthy lifestyles and public awareness [4].

Furthermore, tuberculosis (TB) is the second leading cause of death among adults worldwide. It is equally reported that 13 million people suffer from active TB infection worldwide. These data portray a worrisome globally situation of TB but much more in developing countries where standard of living is low and health services are grossly inadequate. Besides the fact that the tropical countries suffer from high tuberculosis prevalence, they also show an increasing trend of the disease [5]. It is already known that weather variables influence the occurrence of diseases; the influence may be on the reproduction and survival of pathogen or the carriers of pathogens. Moreover, weather condition may encourage the exposure of human to high concentration of pathogen characteristic of places where population (patients and healthy individuals) [6]. Mortality cases arising from tuberculosis and other respiratory diseases among others peaked during the cold time of year. Increase in respiratory infections-related mortality at winter than summer [7],[8].

Understanding the role of weather variables on the morbidity of pulmonary TB has potential for identifying weather related markers that can assist effective allocation and efficient utilisation of health resources in Kulon Progo Regency. Moreover, identifying the role of weather parameters in pulmonary TB morbidity will contribute significantly to planning intervention strategies in response to climate change in this part of the world. Health and health care are considered as an important factor in the quality of life of individuals. Applications of geographic information systems in public health are developed that include management of available health resources, prediction, simulation, management of epidemics, monitoring and control of diseases. In 2014, pulmonary TB was 174 patients in Kulon Progo Regency. TB registers was limited tabular analysis. Management sustainability related patient treatment was limited. TB analysis was still in the form of data aggregation. In the current study investigated in visual formation geographic information system the relationship between monthly, seasonal pattern of pulmonary TB and weather parameters in Kulon Progo Regency. Moreover, the influence of weather parameters on pulmonary TB morbidity in the study area was analysed.

\section{RESEARCH METHOD}

This is cross sectional survey using geographical information system, analyzed by descriptive methods, temporal spatial approach for distribution of pulmonary TB cases, located in Kulon Progo District of Yogyakarta Special Region. The sample included 162 pulmonary tuberrculosis patient in 2014 reported in 25 UPK implementing DOTS (directly observed treatment short-course). The variables were pulmonary tuberrculosis patients and isohyet data.

Survey guide which contained data table of pulmonary TB patient smear-positive, pulmonary TB smear-negative. Administration map of Kulon Progo Regency was on a scale of 1: 25.000 from the Spatial and Environmental Area Infrastructure at Regional Planning Development Agency (BAPPEDA) Kulon Progo Regency.

Data on rainfall (mm) (isohyet map), in 2014 were collected from Meteorological Climatological and Geophysical Agency (BMKG) Geophysic Station of Yogyakarta. This is the agency that is accredited for meteorological data collection, documentation and dissemination. Secondly, retrospective clinic data on pulmonary TB (2011-2014) were extracted from the Diagnostic Index of patients (TB 03) at the District Health Office Kulon Progo. Access to clinic data was granted after the ethical committee and cleared it of any ethical implications by the Medical and Health Research Ethics Committee of the Faculty of Medicine, Gadjah Mada University of Yogyakarta. According to the coding system of the International classification of diseases, pulmonary TB is (A15) respiratory tuberculosis, bacteriologically and histologically confirmed, and (A16) respiratory tuberculosis, not confirmed bacteriologically or histologically. The specific information retrieved from the medical records of the patients includes age, sex, months and year of reporting of the disease. The ages of the patients were categories into 15-24, 25-34, 35-44, 45-54, 55-65, and 65 years and above for analysis purpose. Simple descriptive analyses were employed to compute the quarter, seasonal and annual trends of pulmonary TB. Apart from the quarter and annual trends, two season groups adapted from the Central Statistical Agency of Kulon Progo Regency from the Agriculture and Forestry Office of Kulon Progo Regency.

Rainfall is rainwater amount that supports pulmonary TB cases based on a certain period of time in a region. The data were taken based on Meteorological Climatological and Geophysical Agency (BMKG) Geophysic Station of Yogyakarta. Rainfall intensity is measured in millimetres per hour $(\mathrm{mm} / \mathrm{h})$ over a given duration. Because the heaviest rainfall deluges are likely to be experienced for a short period most rainfall intensity measurements use five minute duration.

IJPHS Vol. 7, No. 1, March 2018: 13-21 
Primary data collection of coordinate points gathered using GPS device DNR type Garmin 60i. The coordinate point of residence of pulmonary TB patients, conducted in front of the house where the pulmonary TB patient lived, and open location (not blocked by walls or trees and sunny weather) to get a good signal. This process takes approximately five minutes. The data entry was done on Microsoft excel spread sheet and imported into ArcGIS software version 10.1 for analysis. Visualization function in geographic information system to see the entire map that has been merged then overlay of some layer maps to generate new spatial information as a whole.

To control for confounding by conditions potentially associated with both rainfall intensity and TB, this study retrieved data on TB03 in District Health Office and confirmed to olther primary health centre, also medical record data observed. Furthermore used information from the Meteorological Climatological and Geophysical Agency (BMKG) Geophysic Station of Yogyakarta for isohyet data, and the Spatial and Environmental Area Infrastructure at Regional Planning Development Agency (BAPPEDA) Kulon Progo Regency for contour data.

\section{RESULTS AND ANALYSIS}

Microbacterium tuberculosis will survive and multiply during the rainy season. In Figure 1, data from the Central Statistical Agency of Kulon Progo Regency from the Agriculture and Forestry Office of Kulon Progo Regency mentioned the highest rainfall in 2011 at the end of the year in February, while the following year at the end of the year, in 2012 in December, then in 2013 again at the beginning of the year in January, and 2014 back in December. In Figure 1, the increase of the number of pulmonary TB patients in the first quarter to the second quarter of 2011, the third quarter to the fourth quarter in 2012 and 2013, the fourth quarter in 2014.

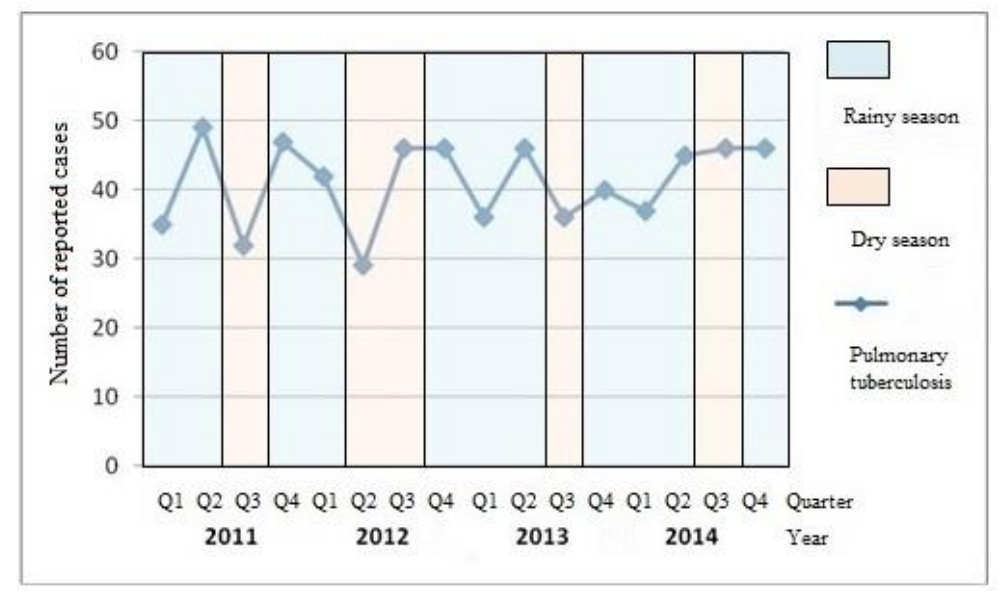

Figure 1. Pulmonary TB patient in 2011-2014

The number of pulmonary TB patients in 2011 to 2014 experienced a continuous increase and decrease in each quarter, but in 2014, the number of pulmonary TB patients from quarter 1 continued to increase until the fourth quarter. In 2014, the highest number of pulmonary TB patients compared to previous years. The discovery of smear-positive more than smear-negative, in the second quarter of 2011 (39 patients), third quarter 2014 (38 patients), fourth quarter (37 patients), second quarter 2013 (36 patients), fourth quarter 2014 (35 patients), third quarter 2012 and second quarter 2014 (34 patients).

Each environmental change, whether occurring as a natural phenomenon or through human intervention, changes the ecological balance and context within which disease hosts or vectors and parasites breed, develop, and transmit disease. Each species occupies a particular ecological niche and vector species sub-populations are distinct behaviourally and genetically as they adapt to man-made environments. The combined effects of environmentally detrimental changes in local landuse and alterations in global climate disrupt the natural ecosystem and can increase the risk of transmission of parasitic diseases to the human population [9]. Greenhouse gas emissions generated by human activity will change Earth's climate. The recent (globally averaged) warming by $0,5^{\circ} \mathrm{C}$ is partly attributable to such anthropogenic emissions. Climate change will affect human health in many ways mostly adversely [3]. High pulmonary TB reporting during intense rainy period in Ile-Ife and Ilorin, Nigeria. Pulmonary TB reported increases during the rainy season; 
intervention strategies for pulmonary TB control should therefore be sensitive to seasonal characteristics of locations for optimum outcomes [10]. Pulmonary TB patients are most prevalent in 2014, compared with the previous 3 years. Therefore, an effort is needed to reduce the incidence of cases, among them with regard to the specification of significant results in this study, as well as other factors not discussed in this study. DOTS strategy has been applied; however it is focused on the discovery and treatment of patients [11].

Climate change refers to long-term shifts in weather conditions and patterns of extreme weather events. It may lead to changes in health threat to human beings, multiplying existing health problems. Humans' vulnerability to the potential health impacts by climate change is evident in literature. As an active agent, human beings may control the related health effects that may be effectively controlled through adopting proactive measures, including better understanding of the climate change patterns and of the compound disease-specific health effects, and effective allocation of technologies and resources to promote healthy lifestyles and public awareness. The following adaptation measures are recommended: 1) to go beyond empirical observations of the association between climate change and infectious diseases and develop more scientific explanations, 2) to improve the prediction of spatial-temporal process of climate change and the associated shifts in infectious diseases at various spatial and temporal scales, and 3) to establish locally effective early warning systems for the health effects of predicated climate change [12].

Active case finding (ACF) in groups at risk during home visits increases the case detection rate in the population and permits the identification of cases that may not be detected through Passive Case Finding (PCF) at health facility level [13]. Patients diagnosed through ACF tended to under-report their TB symptoms and showed low attention to their own health. However, ACF allowed for discovering TB patients earlier than PCF, and this was also the case for alcohol abusing patients. PCF systems should be supplemented with ACF strategies [14]. PCF strategy was less than the maximum applied in the acceleration of TB treatment. PCF method resulted in the pulmonary TB patients active in the community will increasingly not been reported. Intensified Case Finding (ICF) approaches may be needed to control TB transmission; these more aggressive approaches for detectingas yet undiagnosed cases obviously require additional resources to implement [15]. Healthcare staff has committed to identifying TB, but in less resource areas, it seems insufficient, even with PCF. Many TB patients are sent, coming from patients who have not yet been diagnosed. In TB management, something more obvious is needed for PCF.

Cases pulmonary TB reported in Kulon Progo Regency, age-group 45-54 recorded the highest percentage $(25 \%)$, followed by $35-44(21 \%)$ as shown in Table 1 . Other age-group recorded fewer cases while age-group 25-34 (11\%). Moreover, the distribution of pulmonary TB according to gender of patients showed higher percentage of cases among males (54\%). There are many effects of early-life rainfall on the health, education, and socioeconomic outcomes of Indonesian adults, there have link historical rainfall [16]. The number of notification cases among males was slightly more frequent than the cases among females in Mongolia and South Western Cameroon, there were no significant gender difference reported in Hong Kong and India. Few studies used different age's group, the notification number of TB cases was high among young children in India and Hong Kong and declined with increasing age. In South Western Cameroon, the highest number of cases was reported in the age group 21-30, there were no marked seasonal difference was found among all age groups in Japan [17].

Table 1. Demographic characteristics of pulmonary TB patients

\begin{tabular}{cc}
\hline Demograaphic characteristic & $\%$ \\
\hline Age Group & \\
$15-24$ & $24(15 \%)$ \\
$25-34$ & $17(11 \%)$ \\
$35-44$ & $34(21 \%)$ \\
$45-54$ & $41(25 \%)$ \\
$55-65$ & $25(15 \%)$ \\
$>65$ & $21(13 \%)$ \\
Gender & \\
Male & $87(54 \%)$ \\
Female & $75(46 \%)$ \\
Total & $162(100 \%)$ \\
\hline
\end{tabular}

IJPHS Vol. 7, No. 1, March 2018 : $13-21$ 


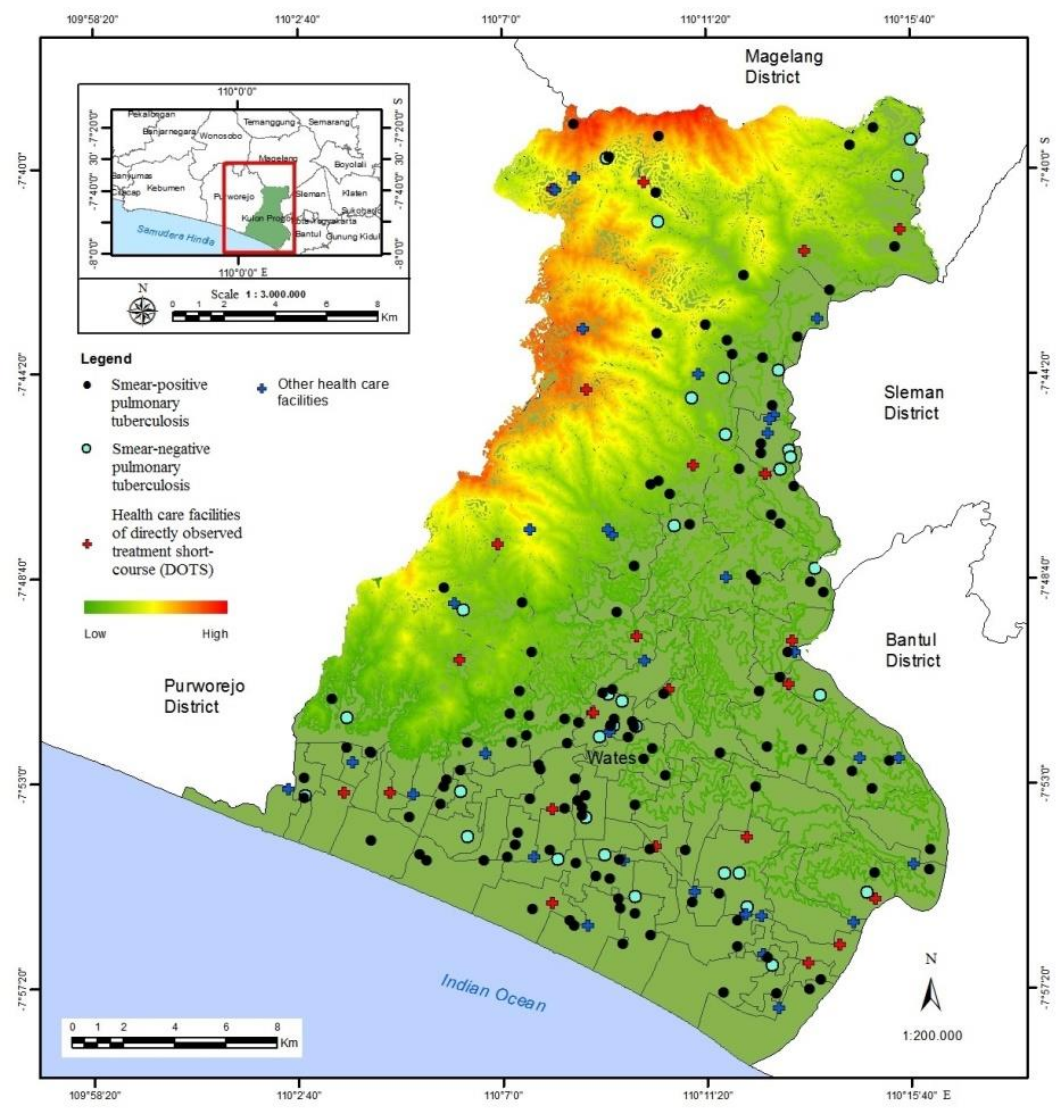

Figure 2. Map of contour for spatial patterns of pulmonary TB

Kulon Progo Regency is one of the four regencies within the Yogyakarta Special Region, Indonesia. It is located on the island of Java. The regency's name stems from the fact that it is situated to the west of the Progo River. The capital is Wates. The greatest part of the population of the regency is farmer. Kulon Progo is surrounded by the Menoreh Hills. The area of the regency is $586.28 \mathrm{~km}^{2}$, and the population was (for January 2014) is 404,155. Kulon Progo Regency was divided into 12 Subdistricts, Temon, Wates, Panjatan, Galur, Lendah, Sentolo, Pengasih, Kokap, Girimulyo, Nanggulan, Kalibawang, and Samigaluh. Kulon Progo Regency is the area of Yogyakarta province, located at the west with the western and northern boundary is the Central Java Province and the south is Ocean Indonesia. Geographically located between $7^{\circ} 38^{\prime} 422^{\prime \prime}-7^{\circ}$ $59^{\prime} 3 "$ south latitude and $110^{\circ} 1{ }^{\prime} 37^{\prime \prime}-110^{\circ} 16^{\prime} 26^{\prime \prime}$ east longitude. The area is 58,627.5 hectares covering 12 districts and 88 villages. Of the $24.89 \%$ area in the southern region which includes Temon and Wates Subdistrict, climbing and strain, $38.16 \%$ in the central region which includes Lendah, Pengasih, Sentolo and Kokap Subdistrict, and 36.97\% in the northern region which include Girimulyo, Nanggulan, Kalibawang and Samigaluh Subdistrict. Area districts between 3000-7500 hectares and the most extensive territory is an area of 7379.95 hectares Kokap Subdistricts while the narrowest region is an area of 3200.239 hectares Wates Subdistrict.

Kulon Progo Regency has a varied topography with an altitude (0-1000 meters above sea level (masl)), which is divided into 3 areas covering, the northern part is the highlands, Menoreh hills with an altitude (500-1000 masl), including Girimulyo, Kokap, Kalibawang, and Samigaluh Subdistrict. The center is a hilly area with an altitude (100-500 masl), including Nanggulan, Sentolo, Pengasih, and Lendah Subdistrict, an area with a slope of $2^{\circ}-15^{\circ}$, categorized as wavy and bumpy, and is a lowland and hilly transition. Southern part is lowland with height 0-100 masl, covering Temon, Wates, Panjatan, Galur, and Lendah Subdistrict [18].

Beside genetic and life-style characteristics environmental factors may profoundly influence mortality and life expectancy. The high altitude climate comprises a set of conditions bearing the potential of modifying morbidity and mortality Whereas living at higher elevations may frequently protect from development of diseases, it could adversely affect mortality when diseases progress. Corroborating and expanding these findings would be helpful for optimization of medical care and disease management in the aging residents of higher altitudes [19]. 
Table 2 shows that the contours in Kulon Progo Regency with high areas extend from south to north in Kokap Subdistrict, Girimulyo Subdistrict, to Samigaluh Subdistrict. Pulmonary TB patients are mostly located in low areas (0-100 masl). Most of the high areas (500-1000 masl) have difficult access, in Girimulyo Subdistricts (50\%), Kokap Subdistricts (42\%), Kalibawang Subdistricts (40\%), and Samigaluh Subdistricts (57\%). Pulmonary TB patient have difficult access if to access health care facilities without motor vehicle, by motor vehicle with long distance, time to access health care facilities $\geq 20$ minutes, and need public transportation.

Table 2. Contour area of pulmonary TB patients

\begin{tabular}{clc}
\hline Contour (masl) & \multicolumn{1}{c}{ Subdistrict } & $\%$ \\
\hline $500-1000$ & Girimulyo & $8(5 \%)$ \\
& Kokap & $12(7 \%)$ \\
& Kalibawang & $10(6 \%)$ \\
& Samigaluh & $7(4 \%)$ \\
$100-500$ & Nanggulan & $14(8 \%)$ \\
& Sentolo & $15(9 \%)$ \\
& Pengasih & $9(6 \%)$ \\
$0-100$ & Lendah & $9(6 \%)$ \\
& Temon & $16(10 \%)$ \\
& Wates & $34(22 \%)$ \\
& Panjatan & $20(12 \%)$ \\
Total & Galur & $8(5 \%)$ \\
& & $162(100 \%)$ \\
\hline
\end{tabular}

Elevation affects temperature which affects the amount of rain. Elevation affects precipitation significantly, especially in a mountain environment. On the windward side of a mountain, precipitation is increased. As air parcel rises due to increasing elevation on the windward side of the mountain, the air parcel cools, condenses, and it rains. Rainfall and altitude were found to be correlated spatially [20]. It is unequivocal that climate change is happening and is likely to expand the geographical distribution of several vector-borne diseases, higher altitudes and latitudes. The upcoming issue of climate change has surfaced as a new threat and challenge for ongoing efforts to contain vector-borne diseases. The possible need to address the threat and efforts made in India have been highlighted. Better preparedness threat of climate change on vector-borne diseases [21].

Altitude had a strong inverse relationship to pulmonary TB notification rates in Mexico, which might be related to the well known changes in alveolar oxygen pressure at different altitudes. Interestingly, several factors traditionally considered as predisposing conditions for the development of pulmonary TB did not correlate with the disease [22]. The mortality rate for TB based on death certificates decreases with altitude of residence, whereas the opposite is observed for pneumonia and influenza. Adjusted death rates for TB decreased with altitude and increased for pneumonia-influenza. Compared to people living below 500 masl, those living between 2000 and 2499 masl had a 58\% mortality rate for TB and a three-fold increase in mortality due to pneumonia-influenza, despite adjustment for poverty, age and gender [23]. Altitude has a stronger influence on the incidence of TB than the other factors. The effect of altitude on TB may reveal new data. The incidence of TB was lower in cities located at high altitude $(\mathrm{P}=0.000)$ and higher in cities with a high population density $(\mathrm{P}=0.000)$. Multivariate analysis showed that the incidence of $\mathrm{TB}$ in low altitude cities was 3.28-fold higher than in high altitude cities $(\mathrm{P}=0.000)$ [24].

Cases pulmonary TB reported in Kulon Progo Regency, rainfall intensity 2000-2200 mm recorded the highest percentage (44\%), followed by $1800-2000 \mathrm{~mm}(23 \%)$ as shown in Table 3 . Other rainfall intensity recorded fewer cases while rainfall intensity $<1600 \mathrm{~mm}(1 \%)$. Rainfall has been implicated in sitespecific waterborne disease outbreaks. Upward trends in heavy precipitation in the United States are projected to increase with climate change. Fifty-one percent of waterborne disease outbreaks were preceded by precipitation events. Outbreaks due to surface water contamination showed the strongest association with extreme precipitation during the month of the outbreak; a 2-month applied to groundwater contamination events. The statistically significant association found between rainfall and disease is important for public health officials, and risk assessors of future climate change [16].

Table 3. Rainfall intensity distribution of pulmonary TB patients

$$
\text { Rainfall intensity (mm) }
$$

IJPHS Vol. 7, No. 1, March 2018 : 13-21 


\begin{tabular}{lc}
\hline$>2400$ & $5(3 \%)$ \\
$2200-2400$ & $15(9 \%)$ \\
$2000-2200$ & $71(44 \%)$ \\
$1800-2000$ & $37(23 \%)$ \\
$1600-1800$ & $32(20 \%)$ \\
$<1600$ & $2(1 \%)$ \\
Total & $162(100 \%)$ \\
\hline
\end{tabular}

Figure 3 describes that data on the isohyet map of Kulon Progo Regency 2014 from Meteorology, Climatology and Geophysics Agency Class I Station of Yogyakarta. Rainfall in Kulon Progo Regency in 2014 with the highest intensity (> $2400 \mathrm{~mm}$ ) in eastern Kecamatan Lendah and the western part of Kokap District, while the lowest intensity $(<1500 \mathrm{~mm})$ in the east of Nanggulan Subdistrict, south of Panjatan Subdistrict and Galur Subdistrict. Pulmonary TB patients are mostly located in areas with high rainfallintensity (2200 -> $2400 \mathrm{~mm}$ ) spreading and stretching in Sentolo Subdistrict, Wates Subdistrict, and Panjatan Subdistrict. Pulmonary TB patients at rainfall intensity> 2400 (3\%), 2200 - 2400 (9\%), 2000 - 2200 (44\%), $1800-2000$ (23\%), $1600-1800$ (20\%), and <1600 (1\%). The more findings of pulmonary TB are indicated by the increasing public awareness to check health in Kulon Progo Regency. Pulmonary TB patients were mostly located in areas with high rainfall intensity $(2200->2400 \mathrm{~mm})$ that spread and stretched from east to west in urban areas Sentolo Subdistrict, Wates Subdistrict and Panjatan Subdistrict.

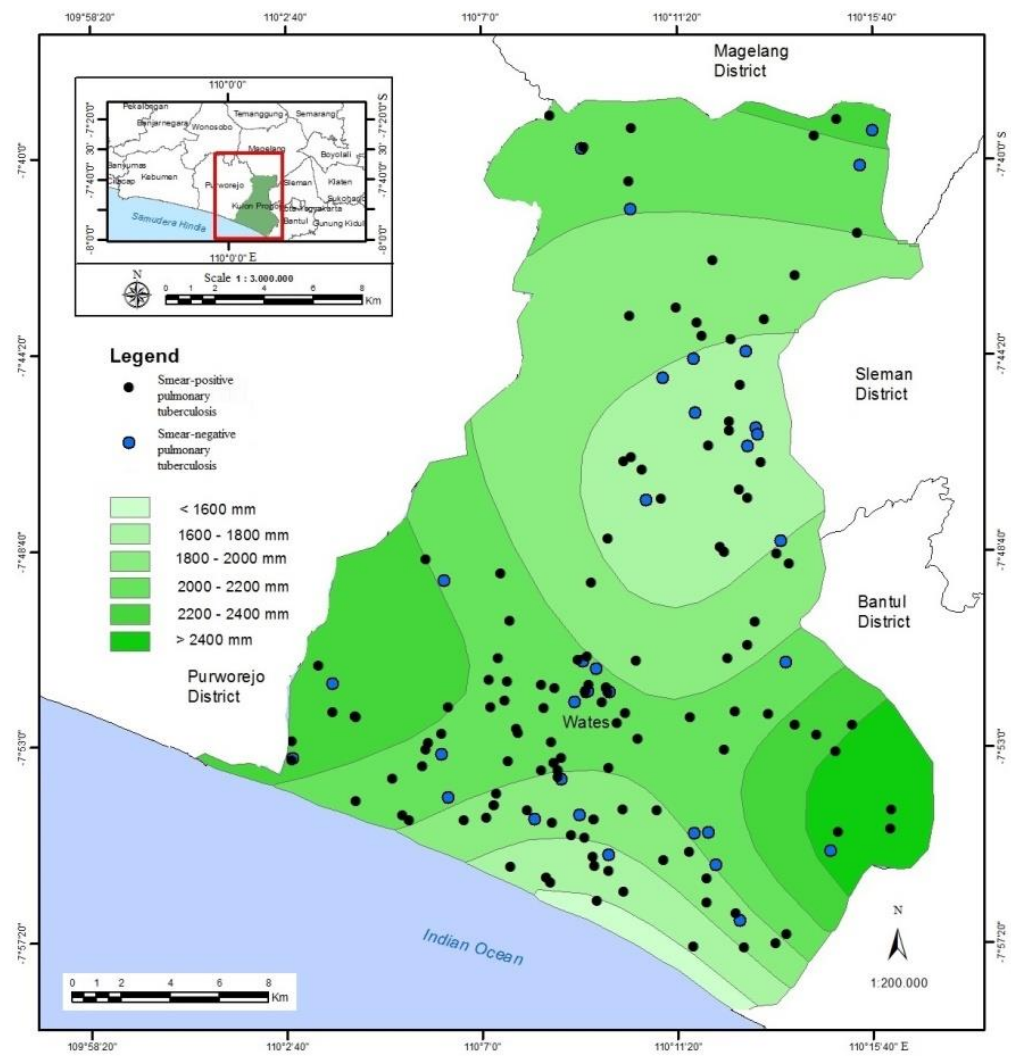

Figure 3. Map of rainfall for spatial patterns of pulmonary TB

Climate variations and trends affect various health outcomes. Global warming has already affected some health outcomes. Estimates of future health effects of climate change over coming decades [3]. The results of this study are consistent with the incidence of pulmonary TB in Ile-Ife and Ilorin, Nigeria. Pulmonary TB cases were reported during wet season I and II at Ile-Ife while at Ilorin, wet season I and short dry season had higher concentration of cases. Periods of high pulmonary TB reporting at Ile-Ife associated with low ambient temperature, high relative humidity and wind speed. At Ilorin, periods of high pulmonary TB cases were characterised by low temperature and wind speed. Early onset of rains in the forest zone was linked with high pulmonary TB reporting during intense rainy period, characterised by high wind speed while 
high cases reporting was in the later phase of rains with low wind speed in the savanna zone. Intervention strategies for pulmonary TB control should therefore be sensitive to seasonal characteristics of locations for optimum outcomes [25].

The results of this pulmonary TB pattern are different from those of 4 seasons in Wuhan, China, with varying results. This increase occurs in the spring seasonal (March), the increased reactivation of the latent TB due to vitamin D deficiency and high PM2.5 concentration, while the summer peak was mainly resulted from the enhanced winter transmission due to indoor crowding in winter, overcrowding of public transportation over the period of the Spring Festival and health care seeking delay in winter [26]. A seasonal pattern of TB with a mostly predominant peak is seen during the spring and summer seasons in 9 countries. The observation of seasonality leads to assume that the risk of transmission of Microbacterium tuberculosis does appear to be the greatest during winter months. Vitamin D level variability, indoor activities, seasonal change in immune function, and delays in the diagnosis and treatment of TB are potential stimuli of seasonal TB disease. Additionally, seasonal variation in food availability and food intake, age, and sex are important factors which can play a role in the TB notification variability [17].

Although this study were able to control for substantial confounding, our results may still be affected by confounding from unmeasured variables, including wind direction and other exogenous factors such as smoking status, living standard, and traveling in high-endemic TB areas. Unmeasured confounding would most likely cause an overestimation of the association between rainfall intensity and TB, but it is not changing this study conclusions.

\section{CONCLUSION}

Spatial pattern distribution of pulmonary TB patients in high rainfall intensity spreads and stretches from east to west areas. Mostly pulmonary TB patients in high contour areas have difficult access. Active case finding and active case monitoring implemented in health care facilities. TB programs attention to pulmonary TB patients in high rainfall intensity areas. District health office of Kulon Progo needs to seek allocation medical resources in the region are still many pulmonary TB but has few medical resources, as well as the mountainous areas whose difficulty access.

\section{ACKNOWLEDGEMENTS}

District Health Office of Kulon Progo, Yogyakarta, TB program holders, Medical Record and Health Information Staff, Information Technology Staff, Regional Infrastructure and Spatial Planning, Meteorological Climatological and Geophysical Agency (BMKG) Geophysic Station of Yogyakarta, Geographic Information System Laboratory, Faculty of Geography, Universitas Gadjah Mada, for granting access to information on pulmonary TB and isohyet data of the study area.

\section{REFERENCES}

[1] Hamada J. I., et al., "Spatial and Temporal Variations of the Rainy Season over Indonesia and their Link to ENSO," J Meteorol Soc Japan, vol/issue: 80(2), pp. 285-310, 2002.

[2] Lee H., "General Rainfall Patterns in Indonesia and the Potential Impacts of Local Seas on Rainfall Intensity," Water, vol/issue: 7(4), pp. 1751-69, 2015.

[3] M. Ajrew and Hales S., "Climate Change and Human Health: Present and Future Risks," Lancet, vol/issue: 367(9513), pp. 859-69, 2006.

[4] Wu X., et al., "Impact of climate change on human infectious diseases : Empirical evidence and human adaptation," Environ Int., vol. 86, pp. 14-23, 2016.

[5] R P., "Tuberculosis--the continuing scourge of India," Indian J Med Res., vol. 103, pp. 19-25, 1996.

[6] Checkley W., et al., "Effects of EI Niño and ambient temperature on hospital admissions for diarrhoeal diseases in Peruvian children," Lancet, vol/issue: 355(9202), pp. 442-50, 2000.

[7] Nakaji S., et al., "Seasonal changes in mortality rates from main causes of death in Japan," Eur J Epidemiol, vol/issue: 19(10), pp. 905-13, 2004.

[8] A. L. F. Braga, et al., "The Effect of Weather on Respiratory and Cardiovascular Deaths in 12 U.S. Cities," Environ Health Perspect, vol. 110, pp. 859-63, 2002.

[9] Patz J. A., et al., "Effects of environmental change on emerging parasitic diseases," Int J Parasitol., vol/issue: 30(12-13), pp. 1395-405, 2000.

[10] Onozuka D. and Hagihara A., "Geographic Prediction of Tuberculosis Clusters in Fukuoka, Japan, Using The Space Time Scan Statistic," BMC Infect Dis., vol. 7, pp. 26, 2007.

[11] Ministry of Health Republic of Indonesia, "National Guidelines for Tuberculosis Control,” Jakarta, 2007.

[12] Wu X., et al., "Impact of climate change on human infectious diseases: Empirical evidence and human adaptation," Environ. Int., vol. 86, pp. 14-23, 2016. 
[13] González O. E., et al., "Pulmonary Tuberculosis Case Detection through Fortuitous Cough Screening during Home Visits," Trop Med Int Heal., vol/issue: 14(2), pp. 131-5, 2009.

[14] Kuznetsov V. N., et al., "A Comparison Between Passive and Active Case Finding in TB Control in the Arkhangelsk Region,” Int J Circumpolar Health, vol. 73, pp. 1-10, 2014.

[15] Yaesoubi R. and Cohen T., "Identifying Dynamic Tuberculosis Case Finding Policies for HIV/TB Coepidemics," Proc Natl Acad Sci U S A, vol/issue: 110(23), pp. 9457-62, 2013.

[16] Akerlof G. A. and Yellen J. L., "Under the Weather: Health, Schooling, and Economic Consequences of EarlyLife," Rainfall, vol/issue: 78(2), pp. 44-9, 2014.

[17] Fares A., "Seasonality of Tuberculosis," J Glob Infect Dis., vol/issue: 3(1), pp. 46-55, 2011.

[18] Central Statistical Agency of Kulon Progo Regency, "Statistical of Kulon Progo Regency 2014," Wates, Central Statistical Agency of Kulon Progo Regency, 2014.

[19] Burtscher M., "Effects of Living at Higher Altitudes on Mortality: A Narrative Review," Aging Dis., 2014.

[20] Al-Ahmadi K. and Al-Ahmadi S., "Rainfall-altitude relationship in Saudi Arabia," Adv Meteorol, vol. 2013, 2013.

[21] Dhiman R. C., et al., "Climate change and threat of vector-borne diseases in India: Are we prepared?" Parasitol. Res., vol/issue: 106(4), pp. 763-73, 2010.

[22] Vargas M. H., et al., "Effect of altitude on the frequency of pulmonary tuberculosis," Int. J. Tuberc. Lung Dis., vol/issue: 8(11), pp. 1321-4, 2004.

[23] Péres P. R. and Franco M. F., "The impact of altitude on mortality from tuberculosis and pneumonia," Int. J. Tuberc. Lung Dis., vol/issue: 8(11), pp. 1315-20, 2004.

[24] A. C. Tanrikulu, et al., "Tuberculosis in Turkey: high altitude and other socio-economic risk factors," Public Health, vol/issue: 122(6), pp. 613-619, 2008.

[25] Oguntoke O., et al., "Influence of Meteorologyparameters on Pulmonary Tuberculosis Morbidity in Two Eco Climatic Zones in Nigeria," Afr J Health Sci., vol/issue: 20(1), pp. 69-76, 2012.

[26] X. Yang, et al., "Seasonal Variation of Newly Notified Pulmonary Tuberculosis Cases from 2004 to 2013 in Wuhan, China," PLoS One, 2014. 